\title{
Nigerian Criminal Justice System and Victims of Crime Neglect in Enugu Urban
}

\author{
Obinna J. Eze \\ University of Nigeria, Nsukka \\ Deborah O. Obi \\ University of Nigeria, Enugu Campus \\ Benjamin Okorie Ajah \\ University of Nigeria, Nsukka
}

\begin{abstract}
As essential area of criminology, crime victims have really never been accorded due recognition in Nigeria. It is in this regard that this paper discusses the Nigerian criminal justice system and the issue of victim neglect in Enugu urban. Using qualitative and quantitative research approaches, a sample of 604 respondents were drawn from Enugu urban. Multi-stage and purposive sampling techniques were used to reach the respondents. Data from both questionnaires and in-depth interviews were collected. We found that most crime victims are highly neglected and there is a lack of cordial relationship between the police and crime victims in Enugu urban. The study recommends the need to consider civil aspect of cases when passing judgments so that crime victims would not lose on two folds, but get partially compensated for their losses. The study also calls for judges to speed up adjudication processes in order not to draw cases to elastic limit where crime victims lose faith in the criminal justice system.
\end{abstract}

Keywords: court, Nigeria criminal justice system, police, victims neglect.

Despite crime victims being an essential part of criminology, they are not accorded required recognition (Ajah, 2019; Nwune, Ajah, Egbegi, \& Onyejegbu, 2019; Gyong, 2010; Yusuf \& Yahaya, 2014). Although, many countries of the western world have revised their criminal codes to incorporate victims' compensation, Igbo (2007) Ajah (2019) noted that developing countries like Nigeria, appear to have forgot or ignored crime victims. Several authors such as Ukwayi and Okpa (2017); Dambazzau (1999) argued that crime victims are passive participants in the criminal justice

Correspondence concerning this article should be addressed to Mr. Benjamin Okorie Ajah* is a Doctoral student and a Lecturer at the School of General Studies, University of Nigeria, Nsukka. Email: okorie.ajah@unn.edu.ng Contribution of Authors:

1. Contributed in the conception and drafting of the manuscript, gathering of data and approval of the manuscript.

2. Contributed in the conception and drafting of the manuscript, analysis and interpretation of data, and approval of the manuscript.

3. Contributed in the conception and drafting of the manuscript, critical revision of the manuscript, proof reading and approval of the manuscript. 
processes, and as such; act as prosecution witnesses. Emphasis on criminal trials, however, is so much concerned about protecting the rights of the suspects. The crime victims are not only denied such protections, they become susceptible to further victimization whenever they stand as witnesses (Yusuf \& Yaya, 2014; Egbegi, Ajah \& Ogbonnaya, 2018; Okpa, Ajah \& Okunola, 2018). Thus, the interests, emotional needs, welfares and rights of crime victims are not considered by the legal process. Rather the criminal justice system (CJS) pay substantial attention on the interests of the suspects who are assumed innocent until proven otherwise by a court of competent jurisdiction.

Globally, there is a public perception that the CJS ignores victims' interests, treats them unfairly and grants more rights to the accused persons despite the fact that studies show that the inputs of crime victims are crucial to have crimes solved and to sustain convictions (Ajah, 2019; Naude, 1997). Many voices of dissent about the adverse position of crime victims have been raised in South Africa (Naude, 1997). Therefore, in the interest of credible and democratic CJS, it is important that the judiciary and the legal profession take note of these negative public perceptions (Naude, 1997).

The plight of crime victims includes denial of welfare services (Egbegi, Ajah \& Ogbonnaya, 2018; Okpa, Ajah \& Okunola, 2018; Gyong, 2010). In Nigeria, National Emergency Management Agency (NEMA) offers emergency relief materials to victims of disasters such as fire, draught, ethnoreligious disturbances, flood, oil spillage, erosion etc. Also, wealthy individuals and corporate bodies have demonstrated similar support to such victims beyond NEMA. The argument has always been that victims of such disasters have suffered personal injuries, loss of lives, material and monetary losses, emotional sand socio-psychological stress; and therefore they need some assistance to ameliorate their hardships (Egbegi, Ajah \& Ogbonnaya, 2018; Okpa, Ajah \& Okunola, 2018). However, even though crimes victims suffer similar hardships, they are rarely given such humanitarian gestures.

In Enugu urban, crime victims face a lot of frustrations. The police often compound their problems by putting them through scourges of exploitation while the courts finish up by eroding the rights of the victims. In a joint forum of Nigerian police and Ministry of Justice 2012, it was recognized that:

'Defense lawyers' sometimes fail to recognize the interest of the state and that of justice. The magistrates on the other hand always rely on Section 167 of the Criminal Procedure Law of Enugu state (CPL), which allows a matter to be dismissed if the complainant is not in court, not minding the reason why the victim of the crime did not attend court. This could be because the victim has been threatened and the absence of a Witness Protection Act fuels the situation. Also, most of the witnesses lack logistics to attend courts' (Daura, 2006:1).

Furthermore, filing for restitution for crime victims since criminal acts can have both criminal and civil contents seems to be extinct. It seems a crime victim cannot be given compensation for the crime committed against her/him. Ruddy (2014) noted that provisions in the justice process are not sufficient to ensure that crime victims derive satisfaction with their involvement in the processes of criminal justice administration as it pertains to restitution, funding and counseling. Wemmers and Cyr (2006:2) noted that 'crime victims do not just want to make demands, but they want their voices to be heard regardless of the outcome. Victims want to express their desires and have their point taken into consideration' (Wemmers \& Cyr, 2006:2). Arguably, the state is the official sanctioning body in criminal matters, but the state is not the only one who the crime perpetrator has offended. Balancing the competing interests in the CJS requires sanctioning of the offender who caused harm to the 
victim. This especially applies to cases where the crime committed was violent crimes such as rape, domestic violence, armed burglary, and assault/battery. However, Cullen and Johnson (2012) noted that the state often plea bargains with the suspects, treats the victims as third parties, gives the victims no say in criminal trial processes, and does little to help the victims. Also, an individual victim needs to be actively involved in the process of criminal trial to feel satisfied, not re-victimized, and comfortably cooperating in the future (Ruddy, 2014).

While the state assumption of criminal proceeding responsibility had indeed ended blood feud, the crime victims now tend to suffer criminal injuries in vain. Ugwuoke (2005) in Ugwuoke (2010) asserts that if criminals have any debt to pay, it is not a debt to the society, but rather to the victims who directly suffered losses. Despite there has been a growing awareness of the plight of crime victims and the need to redress the wrong and to repair the harm committed against them (Ugwuoke, 2005), the CJS appears to forget or ignore crime victims (Igbo, 2007), and up till now, as noted by National Open University (2010), Criminal Procedure Laws of Enugu state have not made any adequate provisions for the compensations of victims of crimes, as distinct from restitution.

Notwithstanding, scientific enquires into the above identified problems are legion (see, for example, Ugwuoke, 2008; Yusuf \& Yahaya, 2014; Gyong, 1996; Ani, 2011; Ajah \& Nweke, 2017, Nweke \& Ajah 2017; Ukwayi \& Okpa, 2017; Ajah, 2018; Adelani, 2018; Nwune, Chikwelu, Ajah \& Obiefuna, 2018; Ajah, 2019). These studies are important, since they contribute significantly in understanding the problems and challenges of the criminal justice system and their way out. However, none of the aforementioned studies has linked the criminal justice system operations to the challenges encountered by crime victims in Nigeria. This paper therefore fills this research gap.

\section{Conceptual Clarifications \\ Nigeria Criminal justice system}

There are varied conceptions on criminal justice system (CJS). Ajah (2019) and Dambazau (2007) averred that the CJS is either defined as a legal process or as an academic discipline. As a legal process, CJS involves the procedure of processing suspects from the point of arrest to the final disposal of the case. On the other hand, as an academic discipline, CJS provides a thorough understanding of the CJS in relation to the society. Bohm and Haley (2002) describe the CJS as both an institution and a system. As an institution of social control, CJS is said to differ from others in two important ways. First, the role of CJS is restricted officially to persuade people to abide by limited range of social values (Ajah, 2019; Ajah \& Nweke, 2017; Nweke \& Ajah 2017, Ukwayi \& Okpa, 2017; Ajah, 2018; Adelani, 2018; Nwune, Chikwelu, Ajah \& Obiefuna, 2018; Ajah, 2019). Secondly, CJS is the society's last line of defence. This shows that the society turns to the CJS only after other institutions of social control have failed. On the other hand, CJS is also seen as a "system". A system is an organized or complex whole, an assemblage or combination of things or parts forming -a complex or unitary whole. It is an entity which comprises of interconnected and interdependent parts which collectively constitute the whole, and still collectively work or function to ensure the maintenance and continuity of the whole system. Based on this systemic idea, CJS has been conceived as machinery through which a criminal or a suspect is processed and subsequently disposed (Dambazzau, 1999). Thus, the CJS is responsible for the regulation and control of criminal behavior.

Criminal justice system (CJS) is said to be valuable in two ways (Ajah \& Okpa, 2019; Dambazau, 2007); first, it is an instrument of effective crime reduction, incapacitation, deterrence and rehabilitation; second, it is an instrument of justice by holding offenders accountable for their offences, and intermittently protecting constitutional rights of the accused. 
Basically, the police, the courts, and prisons constitute the major components or agencies of criminal justice (Ajah, 2019; Ajah \& Nweke, 2017; Nweke \& Ajah 2017, Ukwayi \& Okpa, 2017; Ajah, 2018; Adelani, 2018; Nwune, Chikwelu, Ajah, \& Obiefuna, 2018; Ajah, 2019). The statutory functions of the Nigeria criminal justice system follows that the police are responsible for detecting crime and apprehending people who violate criminal law, the courts decide guilt or innocence, and sentence those who are convicted or those who plead guilty, the prisons or correctional institutions carry out the sentence of the courts and rehabilitation process of convicts.

\section{Victims of crime neglect}

Although the same situation that produces criminal offenders also produces crime victims, crime victims are deemed to be grossly neglected in Nigeria. Nigerian Penal code section 78 provides for compensation of crime victims. This law is however observed more in the breach. Ekumankama (2002) in Nyiyongo (2006) observed that magistrates have adduced several reasons for their inability to comply as follows:

- Not having the jurisdiction to award compensation where the amount involved is above their statutory power.

- Failure of the police to prove the actual value of goods stolen.

- Police non application for compensation at the end of the case immediately after judgment is pronounced.

In reaction to the above, Ekumankama (2007) asserts that;

There is nothing prohibiting the courts from ordering compensation. For the high court and other superior courts, there is no problem as they have unlimited jurisdiction. The magistrate courts pose these problems. We must submit that neither section 78 of the penal code nor section 31 of the criminal code restrict the jurisdiction to offer compensation in any manner. Any interpretation to the contrary is an importation into the sections what they are not intended to serve...proof of the actual value of property lost should not be one based on proof beyond reasonable doubt like the offence itself...the court can go ahead to order compensation whether the prosecution applied for it or not. To think otherwise would be doing injustice to the victims (Ekumankama, 2007:37-8)

However, the ambiguity of section 78 of the penal code (1963) calls for compensation of victims by stating that such compensation should be enforced as if it were a fine to the state, has only made the victim lose his/her compensation rights to the state.

\section{Method}

\section{Study design and location}

This study adopted a cross-sectional survey research design. This design is considered appropriate for this study because it has the capacity to accurately gather necessary information within a limited timeframe on large sample. The design is economical and focuses on studying large and small populations with emphasis on relative incidence, distribution and interrelations of sociological and psychological variables (Isangedighi, Joshua, Asim \& Ekuri, 2014). The study was conducted in Enugu urban which includes Enugu north (Coal camp, Ogui, Asata, Okpara avenue, Independence lay-out, and New haven), Enugu east (Abakpa) and Enugu south urban (AmechiUwani), located in Enugu State, Nigeria. 


\section{Participants and procedures}

The target population for this study is 389,158 , who were the adult residents aged 18 years and above in the study area (NPC, 2010). Using Alien Taro Yamane (1967) method of sample size determination, with a $95 \%$ confidence level and level of maximum variability $(P=0.04)$, a sample of 624 was computed-out of which -604 respondents were finally used after data collation, gleaning, cleansing and analysis. The multi-stage sampling technique that involves successive random sampling was adopted in the selection of respondents from the Local Government Areas (LGAs), towns, streets and households. Multi-stage method is relevant to this study because the population is made up of several clusters: local government areas, towns and streets. The researchers clustered Enugu state into its 17 LGAs which were further grouped into urban and rural LGAs. From this categorization, three LGAs were purposively selected. In this light, Enugu North, Enugu South Urban and Enugu East were purposively selected from the Enugu urban LGAs.

\section{Data Collection Procedures and Ethical Clearance}

This study adopted mixed methods of scientific enquiries, following quantitative and qualitative approaches in its data collection. The instruments for data collection were structured questionnaire and unstructured In-Depth Interview (IDI). The research instruments were selfadministered by two researchers. Ethical clearance was obtained from ethical committee of the University of Nigeria Teaching Hospital, Ituku-Ozalla, and National Health Research Ethics committee (NHREC). Participation in the research was risk-free, anonymous, voluntary, and confidential based on informed consent of all participants, hence we made no reference to sex, in as much as the participant fall under the category of the age 18 years and above. Of the 624 questionnaires distributed, 621 were returned with 7 not properly completed and thus were rejected while 3 were not returned and thereby leaving us with a total of 604 copies for analysis. In order to complement data generated through questionnaire instrument, in-depth interviews were conducted on four police officers, three prison officers and three court officials; totalling 10 interviewees. Each respondent's interview lasted between 35 and 90 minutes. The interviewees disapproved of our attempts to record their responses in audiotape, so only handwritten notes were taken.

\section{Data Analysis}

Both qualitative and quantitative components of the data collected were subjected to scrutiny before cleansing, coding and analysis. The quantitative data analysis was performed using International Business Machine (IBM) Statistical Packages for Social Sciences (SPSS) version 21. Utilizing descriptive statistics, the results of IBM SPSS were further analyzed, interpreted and organized using tables, frequencies and charts. The qualitative data were analyzed using manual thematic method, where the responses were transcribed with some catchy phrases retained in their original versions and contexts in the form of extracts or excerpts (see the result section for details). 
Table 1

\section{Results}

Distribution of the respondents by the category of crime that occurs more in their area

\begin{tabular}{lll}
\hline Reasons & Frequency & Percentages (\%) \\
\hline Murder & 103 & 17.1 \\
Smuggling & 210 & 34.8 \\
Theft and stealing & 177 & 29.3 \\
Armed Robbery & 90 & 14.9 \\
Kidnapping & 24 & 4.0 \\
Total & $\mathbf{6 0 4}$ & $\mathbf{1 0 0 . 0}$ \\
\hline
\end{tabular}

Field Survey, 2019

Table 1 above shows the distribution of respondents on the crime that occurs more in their area. It shows that $34.8 \%$ of the respondents were of the opinion that smuggling occurs more in their area, $29.3 \%$ opined that theft and stealing occur more in their area, $17.1 \%$ were of the opinion that murder occurs more in their area, $14.9 \%$ and $4 \%$ of the respondents were of the opinion that armed robbery and kidnapping occur more in their area. This shows that more of the respondents (34.8\%) were of the opinion that smuggling constitutes the most dominant crime in Enugu urban. This implies that smuggling, theft and stealing are the most common types of crime in Enugu urban, as a result; it can be inferred that property crime is the most dominant type of crime in Enugu urban.

\section{Table 2}

Distribution of the respondents by their assessment of the rate at which such crimes occur (frequency of occurrence)

\begin{tabular}{lll}
\hline Responses & Frequency & Percentage (\%) \\
\hline High & 155 & 25.7 \\
Low & 199 & 32.9 \\
Stable & 226 & 37.4 \\
No Idea & 24 & 4.0 \\
Total & $\mathbf{6 0 4}$ & $\mathbf{1 0 0 . 0}$ \\
\hline
\end{tabular}

Field Survey, 2019

The information presented in Table 2 shows the distribution of the respondents on the rate at which they perceive the occurrence of crimes identified in Table 1 . It shows that $25.7 \%$ of the respondents perceived such crimes as occurring at a high rate, 32.9\% perceived them as occurring at a low rate, $37.4 \%$ opined that such crimes rate of occurrence is stable while $4 \%$ claimed to have no idea of the rate at which such crimes occur in Enugu urban. The implication is that majority of the respondents' perceived crimes in Enugu urban as occurring at a stable rate which implies that it is neither on the increase nor decrease but continues at the same rate unabated.

\section{Table 3}

Distribution of the respondents on what they think is the major crime victims agitations within the criminal justice system.

\begin{tabular}{lcc}
\hline Factors & Frequency & Percentage (\%) \\
\hline Extortion & 146 & 24.2 \\
Lack of Victim protection Right Act & 121 & 20.0 \\
Lack of information on court proceedings & 175 & 29.0 \\
Lack of compensation for civil wrong & 162 & 26.8 \\
Total & $\mathbf{6 0 4}$ & $\mathbf{1 0 0 . 0}$ \\
\hline
\end{tabular}

Field Survey, 2019 
Table 3 above shows information on the distribution of the respondents on what they think is the major crime victims' agitations in the criminal justice system. From the table, $24.2 \%$ of the respondents indicated extortion, $20 \%$ indicated lack of victims protection right, $29 \%$ indicated lack of information on court proceedings, while $26.8 \%$ indicated lack of compensation for civil wrong. This implies that lack of information on court proceedings ranks highest as one of the major crime victims agitations, followed by lack of compensation for civil wrong.

Information obtained through the in-depth interview revealed that lack of compensation plan in the criminal justice system is the major crime victims' agitations not just in Enugu state, but in all states of the federation. For example, responding to the question on measures put in place to address the plight of crime victims in Nigeria, one of the respondents said "It is part of the functions of police and court to address the issue of victims but often, there is lack of plan of how to attend to this people as they are more preoccupied with fighting the perpetrators" (IDI, 30 years, Prison Officer, June 2019). Another respondent regarding this said:

Yes, in the Nigeria police force, there is a human right section, which is a channel through which the crime victims can further pursue their claims. But most times, the process is a long one that requires consistency on the part of the victim. So this makes some of the victims to feel it is unnecessary. In some cases where the perpetrator is known and possibly apprehended, the two parties might go behind and settle and then start talking of withdrawal of the case. Also you might have cases where the police force lacks the resources to care for the victims (IDI, 45 years, Police Officer, June 2019).

\section{Table 4}

Distribution of the respondents on whether the police collaborate with residents in their area in crime reduction

\begin{tabular}{lcc}
\hline Responses & Frequency & Percentage (\%) \\
\hline Yes & 140 & 23.2 \\
No & 279 & 46.2 \\
No Idea & 185 & 30.6 \\
Total & 604 & $\mathbf{1 0 0 . 0}$ \\
\hline
\end{tabular}

Field Survey, 2019

Table 4 shows the distribution of respondents on whether the police collaborate with residents in their area in crime reduction campaign. The finding shows that $23.2 \%$ of the respondents were of the opinion that the police collaborate with residents in their area to reduce crime, $46.2 \%$ were of the opinion that the police do not collaborate with residents in their area to reduce crime while $30.6 \%$ don't know whether the police collaborate with residents in crime reduction. This implies that more of the respondents (46.2\%) believe that there is absence of collaboration between the police and people who reside in their area in controlling crime. It can therefore be said that there is low or absence of community policing in Enugu urban. 


\section{Table 5}

Distribution of the respondents on the nature of collaboration existing between police and residents in crime reduction

\begin{tabular}{lcc}
\hline Responses & Frequency & Percentage (\%) \\
\hline Cordial & 116 & 19.2 \\
Not Cordial & 305 & 50.5 \\
Don't Know & 183 & 30.3 \\
Total & 604 & $\mathbf{1 0 0 . 0}$ \\
\hline
\end{tabular}

Field Survey, 2019

Table 5 shows distribution of respondents on the nature of relationship they perceived as existing between the police and residents in crime reduction. The findings show that $19.2 \%$ perceived an existence of cordial relationship between the police and residents in crime reduction, $50.5 \%$ perceived absence of cordial relationship between the police and residents in crime reduction, while $30.3 \%$ do not know about the nature of relationship existing between the police and residents in crime reduction in Enugu urban. This implies that majority of the respondents $(50.5 \%)$ believe the nature of collaboration existing between the police and residents in crime reduction is not cordial. This implies that the majority of people in Enugu urban do not collaborate cordially with police in crime reduction.

Information obtained through in-depth interview do not perceive lack of cordial relationship between the police and residents, but pointed that often, police professionalism does not permit them to act or relate friendly with people which makes people to perceive them of not having human sympathy. One of the respondents had this to say:

I think the relationship between the criminal justice system, like the police for example with victims of crime is cordial. Professionally, the police are neutral in all matters, but you see people wanting the police to act in their own personal interests. But we cannot do that, we have to protect the law. So on such occasion, the people might start perceiving the police as lacking human sympathy and so on (IDI, 39 Years, Police Officer, June, 2019).

Another respondent on this argued that it might make the people who are deemed to be sentimental to feel there is absence of cordial relationship between the police and residents in crime reduction. He said: "The relationship is targeted towards attaining justice, which requires the police personnel to be as objective as possible, else they contravene the law. However, this is the point at which people who are the victims perceives otherwise because they are likely to be sentimentally loaded from their victim position" (IDI, 52 years, Legal practitioner, June, 2019).

\section{Table 6}

Distribution of the respondents on the kind of criminal proceedings outcome that seems more appealing to most crime victims

\begin{tabular}{lll}
\hline Level of Effectiveness & Frequency & Percentage (\%) \\
\hline Incarceration & 82 & 13.6 \\
Restitution & 370 & 61.3 \\
Banishment & 104 & 17.2 \\
Others & 48 & 7.9 \\
Total & $\mathbf{6 0 4}$ & $\mathbf{1 0 0 . 0}$ \\
\hline
\end{tabular}


Table 6 shows the distribution of respondents on the kind of criminal proceedings outcome that seems more appealing to most crime victims. The findings show that $13.6 \%$ of the respondents indicated incarceration as the kind of criminal proceeding outcome that seems more appealing to most crime victims, $61.3 \%$ indicated restitution, $17.2 \%$ indicated banishment while $7.9 \%$ indicated other proceedings like probation, parole and so on. This shows that majority of the respondents $61.3 \%$ were of the opinion that restitution is the criminal proceedings outcome that seems more appealing to crime victims in Enugu urban. The implication of this is that most crime victims will prefer it if restitutions become the outcome of criminal proceeding in Enugu urban.

Information obtained through the in-depth interview are also in line with this as it revealed that crime victims would desire a criminal proceeding in which victims recover their lost if it was an incidence of property crime or get adequate compensation if it was cases of personal crime. Responding to question on the criminal proceedings plan most victims will find appealing, the respondent said:

About $40 \%$ of the victims would want the criminal to be duly punished so as for $\mathrm{him} /$ her to learn a lesson, while about $60 \%$ of the victims would be of the opinion that if the criminal can return the stolen property or if adequate compensation can be provided, then there will be no need to make a case. This percentage is based on case reported at the counter in the police stations (IDI, 34 years, Police Officer. June 2019).

\section{Table 7}

Distribution of the respondents on whether they will like to see the criminal justice agencies pursue a compensational sentencing in their area

\begin{tabular}{lll}
\hline Options & Frequency & Percentage (\%) \\
\hline Yes & 329 & 54.5 \\
No & 274 & 45.4 \\
Don't Know & 1 & 0.2 \\
Total & $\mathbf{6 0 4}$ & $\mathbf{1 0 0 . 0}$ \\
\hline
\end{tabular}

Field Survey, 2019

Table 7 shows the distribution of respondents on whether they will like to see the criminal justice agencies pursue compensational sentencing in their area. The finding shows that $54.5 \%$ of the respondents will like to see the criminal justice agencies pursue a compensational sentencing in their area while $45.4 \%$ will not want that to happen. This shows that majority of the respondents will like to see the criminal justice agencies purse a compensational sentencing in their area. The implication of this is that most victims of crime will appreciate it more if at the end of each criminal proceeding, they are refunded of their stolen properties or compensation is paid to them.

\section{Discussion}

Empirical evidence shows that property crime is the most dominant type of crime in Enugu urban. This was indicated by the respondents as follows; 34.8\% (smuggling), 29.3\% (theft and other stealing), and $14.9 \%$ armed robbery. Similarly, the distribution of the respondents on the rate at which they perceive the occurrence of those crimes identified in Table 1 indicates that more of the respondents' perceive crime in Enugu urban as occurring at a stable rate which implies that it is neither on the increase nor decrease but continues at the same rate unabated. Though, Table 3 indicates that there is a high rate of police patrol in Enugu urban, such has not been able to reduce the rate of crime occurrence in their area as majority of the respondents in Table 2 perceived the rate of crime 
occurrence in their area to be stable. We found that starting from the police through the courts, crime victims are subjected to substantial neglect. Our findings are consistent with those reported by Ajah (2019) and Gyong (1996) whom observed that crime victims mostly play distinctively secondary role of mainly reporting crimes. Also, in consonance with (Ajah, 2019; Ajah \& Nweke, 2017; Nweke \& Ajah 2017, Ukwayi \& Okpa, 2017; Ajah, 2018; Adelani, 2018; Nwune, Chikwelu, Ajah \& Obiefuna, 2018; Ajah, 2019), we found that while the police is required by law to treat the accused as innocent until proved guilty, these legal rights are denied the victim.

Empirical evidence from our study revealed that residents of Enugu urban do not perceive the police as effective in detecting and controlling crime. This was indicated by more than half of the respondents who opined that the way victims are treated by the police when they report cases is very unpleasant. Another salient finding of the study is that the perceived working relationship between crime victims and the police in criminal investigation in Enugu urban is not collaborative. This was made known by $46.2 \%$ respondent on table 4 , and $50.5 \%$ respondent on table 5 . This further implies that the residents of Enugu urban are not confident that the criminal justice system can competently help them to be duly compensated for the crime committed against them. Furthermore, we found that crime victims in Enugu urban do not confidently rely on the criminal justice agencies to recover their stolen properties, as most victims resort to traditional sooth saying procedure to recover their stolen item. This is in agreement with Nsereko (1992) who observed that in pre-colonial African societies, reconciliation and restitution were regarded as important to restore the harm caused by crime. But since state assumption of criminal prosecution, crime victims have been relegated to double losers, first to the criminal, and second in favor of the state. This aligned with Naude (1997) who mentioned oppression and unjust laws; Ukwayi, Okpa and Dike (2018); and Danbazzau (2007) who identified the colonial heritage of the Nigerian police as the major impediments towards crime victim compensation. Our study also revealed that restitution appeals more to crime victims in Enugu urban than any form of punitive sentence.

\section{Conclusions}

On the basis of the findings, we conclude that issues of crime victims neglect are attitudinal. First, on the part of the criminal justice system, and second, on the lack of collaboration between the police and residents in Enugu urban. As the gate keeper of the justice system, the police determine who enters and who does not enter into the criminal justice process, and the level of collaboration between the police and crime victims' helps to make a case victorious through providing valid evidence. Similarly, smooth and trustworthy collaboration of the police and crimes victim is essential towards ameliorating crime victims' neglect. We therefore recommend that in passing criminal judgment, the judges should consider the civil aspect of cases so that crime victims will not lose on two folds but at least get compensated for their losses. Thus, with time the decided cases shall form judicial precedents upon which future cases of similar nature can be decided, thereby leading to careful evolvement of operational law. There is also need for the judges to speed up the adjudication processes so as not to draw cases to elastic limit whereby the parties (especially the complainants) lack faith in the criminal justice system. Finally, while the police strive towards maintaining highest degree of professionalism, the ministry of interior should adequately provide funding towards criminal investigations. 


\section{References}

Adelani, A. (2018, April 7). Jailbreaks: 1,133 prisoners on the loose-Investigation. Punch Newspapers, p46.

Ajah, B. O. (2018). Criminal Justice Administration and Panic of Prison Correction in Nigeria. Journal of Law and Judicial System 1 (2), 1-8

Ajah, B. O. (2018). Educational Training of Inmates in Awka and Abakaliki Prisons, Nigeria. International Journal of Criminal Justice Sciences 13 (2), 299-305.

Ajah, B. O. \& Okpa, J. T. (2019). Digitization as a solution to the problem of awaiting-trial inmates in Ebonyi State, Nigeria. International Journal of Criminal Justice Sciences 14 (2), 199-207.

Ajah, B. O. (2018). Juvenile Justice Administration and Child Prisoners in Nigeria. International Journal of Criminal Justice Sciences 13 (2), 438-446

Ajah, B. O. (2019).Agricultural training of inmates and challenges facing food security in Nigeria, a study of Awka and Abakaliki prisons. Research Journal of Food and Nutrition, 3 (1), 3-10.

Ajah, B. O., \& Nweke, J. O. (2017). Prison facilities and the welfare of inmates in Nigeria: a studyof Abakaliki and Awka prison. World Applied Sciences Journal, 35 (3): 361-369.

Alemika, E.E.O. (2011). Criminal victimization and public perceptions of safety and policing. Crime victimization, safety and policing in Nigeria. Monograph Series, No. 9, 23-35. Lagos: CLEEN Foundation.

American Sociological Association (2011). Available at: http://www.asanet.org/about/ethics.cfm

Ani, C.C. (2011). Reforms in the Nigerian Criminal Procedure Laws. NIALS Journal on Criminal Law and Justice, 1, 53-90.

Association of Social Anthropologists (1999). Ethical Guidelines for Good Research Practice.ASA Ethics. Available at: https://www.theasa.org/ethics/guidelines.shtml

Babbie, E. (1989). The Practice of Social Research. Belmont CA: Wadsworth.

Bohm, R. B. \& Haley, K. N. (2002). Introduction to Criminal Justice 3rd Edition. New York: McGraw Hill.

Bulmer, M. (2001). The ethics of social research. Gilbert N. (Ed.). In: Researching Social Life. (pp. 4557). London: Sage.

Cullen, F. T., \& Cheryl L. J. (2012).Correctional theory: context and consequences. Thousand Oaks, Calif.: SAGE, Print.

Dambazau, A. B. (2007). Criminology and Criminal Justice Kaduna: Nigerian Defense Academy Press.

Dambazau, A. B. (2007). Criminology and criminal justice. Ibadan: Spectrum Books Limited.

Dambazau, A.B. (2009). Criminology and criminal justice ( ${ }^{\text {nd }}$ Ed.) Ibadan: Spectrum Books Limited.

Daura, M. (2006). Inaugural forum: at the Police Superior Officers Mess. Enugu. Accessed February 6, 2015 from http://www.prawa.org/nigeria-police-and-ministry-of-justiceenugu launch-ajoint forum/

Ekumankama, D.U. (2002). Law, corruption and other economic crimes in Nigeria today: problems and solution. Jos: New World Publishers.

Egbegi, F. R., Ajah, B. O., \& Ogbonnaya C. (2018). Combating boko haram insurgency through a superior ideology: the role of the federal government. European Journal of Political Science Studies, 1 (2), 13-22.

Gyong J.E. (1994). Victims of common crimes in Kaduna state. Unpublished Ph.D thesis Submitted to Sociology Department, Ahmadu Bello University, Zaira.

Gyong, J.E. (1989). "The Victim of Crime and the Criminal Phenomenon", a paper presented at the Report of Sociology Staff Seminar, ABU, Zaria.

Gyong, J.E. (2010). Criminal victimization and the reporting of crime in kaduna state: towards integrating the victim of crime into criminological discourse. Current Research Journal of Social Sciences 2(5), 288-295. 
Gyong, J.E. (1996).The Neglect of victims of common crimes In Nigeria: The case of Kaduna State. Unpublished Ph.D. Thesis, A.B.U., Zaria.

Igbo, E.U.M. (2007). Introduction to Criminology. Nsukka: University of Nigeria Press Ltd.

Isangedighi, A. J., Joshua, M. T., Asim, A. E., \& Ekuri, E. E. (2006). Fundamental of research and statistics in education and social science. Calabar: University of Calabar Press.

Munhall, P. L. (1988). Ethical considerations in qualitative research. Western Journal of Nursing Research, 10(2), 150-162.

National Committees in for Research Ethics in Norway (2006). Guidelines for Research Ethics in the Social Sciences, Law and Humanities. Oslo: De nasjonale forskningsetiske komiteer. Available at:https://graduateschool.nd.edu/assets/21765/guidelinesresearchethicsinthesocialsciences I.awhumanities.pdf

National Open University (2010). Victims of Crime and Human Rights Violations: CSS 452: Course Guide. Accessed $\quad$ December $31, \quad 2015$ from http://www.nou.edu.ng/uploads/NOUN_OCL/pdf/pdf2/ CSS\%20452.pdf

National Health Research Ethics Committee [NHREC] (2020). Guidance on ethical conduct of research in Nigeria. Abuja: Federal Ministry of Health. Available at: https://nhrec.net

Naude, B. (1997). Dealing with the victims of crime-the role of the legal profession. Consultus, 10(1), 57-59.

Nsereko, N.(1992). Victims of crime and their rights. Criminology in Africa. Edited by Mushanga M, Rome: UNICRI.

Nweke, J. O. \& Ajah, B.O. (2017). Challenges facing vocational training of prison inmates in Nigeria: a study of Abakaliki and Awka prisons. Ponte: International Journal of Sciences and Research, 73 (5), 33-48.

Nwune, E. C., Ajah, B. O., Egbegi, F. R., \& Onyejegbu, D. C. (2019). Across the Wall: the Perception of Rehabilitation, Reformation and Reintegration Programmes in Anambra State Prison Command. Journal of Law and Judicial System 2 (2), 13-22.

Nwune, F. R., Chikwelu, E., Ajah, B. O., Obiefuna, C. E. (2018). Correctional Programmes within the Prison Community: The Views and Perception of Inmates and Staff in Anambra State Prisons, Nigeria. Developing Country Studies 8 (6), 1-7.

Nyiyongo (2006). A Journal of the Nigeria Sociology and Anthropology Students Association, Benue State University, Makurdi, Cited in the Social Analyst, 5, 1.

Okpa, J. T., Ajah, B. O, \& Okunola, R. A. (2018). Religious fundamentalism and sustainable development in Nigeria: understanding the intricacies. Journal of Religion and Theology, 2 (2), 12-18.

Resnik, D. B. (2015). What is ethics in research and why is it important? USA: National Institute of Environmental Health Sciences. Available at: https://www.niehs.nih.gov/research/resources/ bioethics/whatis/index.cfm

Ruddy, R. (2014).The victim's role in the Justice process. Internet Journal of Criminology, ISSN 2045 6743. Retrieved February 29, 2016 fromhttp://www.internetjournalofcriminology.com Ruddy The Victim's Role-in the Justic Pocss_IJC_Jan_2014.pdf

Smith, D. (2003). Five principles for research ethics. Monitor on Psychology, 34(1), 56. Available at: https://www.apa.org/monitor/jan03/principles.aspx

Ugwoke, C.U. (2008). The Plight of Victims in Nigeria: A Study of Public Perception in Enugu State, Nigeria. Journal of the Institute of African Studies, 8 (1\&2) 69-76.

Ugwoke, C.U. (2010). Criminology: Explaining crime in the Nigerian context. Nsukka: Great AP Express LTD.

Ugwoke, C.U. (2008). The Plight of Victims in Nigeria: A Study of Public Perception in Enugu State, Nigeria. Journal of the Institute of African Studies, 8 (1\&2) 69-76. 
Ugwuoke, C.U. (2005). Restitution of crime victims in Nigeria: A study of public perception in Enugu state. Ph.D thesis, Dept. of Sociology/Anthropology University of Nigeria, Nsukka.

Ukwayi, J. K., Okpa, J. T., \& Dike, E. (2018). Ethnic and religious conflict in Jos, Plateau State, Nigeria: a dangerous threat to human existence and business activities. Research on Humanities and Social Sciences 8 (8), 31-37.

Ukwayi, J. K., \& Okpa, J.T. (2017). Critical assessment of Nigeria Criminal Justice System and the Perennial Problem of awaiting trial in Port Harcourt Maximum prison, Rivers State. Global Journal of Social Sciences, 16, 17-25.

Vilma, Z. (2018). Implementing ethical principles in social research: Challenges, possibilities and limitations. 10.2478 /vtrr-2018-0003 Vocational Training: Research and Realities, 29(1):19-43

Wemmers, J., \& Cyr, K. (2006). "What Fairness means to Crime Victims: A Social Psychological Perspective on Victim-Offender Mediation." Applied Psychology in Criminal Justice. N.p., n.d. Web. 31 July 2013

Yamane, T.A. (1967). Statistics: An introductory analysis $2^{\text {nd }}$ ed; New York, Happer and row.

Yusuf, U.A., \& Yahaya, S.S. (2014). Crime victims and criminal justice criminal administration in Nigeria. Global journal of interdisciplinary social sciences: G.J.I.S.S..3(5):48-52.

Received: Feb 11, 2020

Revisions Received: Aug 10, 2020 